\title{
VOLATILITY SPILLOVER EFFECTS BETWEEN FUTURES AND SPOT MARKETS - CASE OF AGRICULTURAL COMMODITY DERIVATVES IN INDIA
}

\author{
RANGANATH. G $\mathbf{1}$, R. VENKATRAM ${ }^{2} \&$ K. MAHENDRAN ${ }^{3}$ \\ ${ }^{I}$ Research Scholar, Department of Agricultural \& Rural Management, Tamil Nadu \\ Agricultural University Coimbatore, Tamil Nadu, India \\ ${ }^{2}$ Director, Planning and Monitoring, Tamil Nadu Agricultural University Coimbatore, Tamil Nadu, India \\ ${ }^{3}$ Professor and Head, Department of Agricultural \& Rural Management, Tamil Nadu \\ Agricultural University Coimbatore, Tamil Nadu, India
}

\begin{abstract}
Volatility spillover is described as the extent to which the volatility in one market affects the other and it is necessary to model the relationship between the volatilities of both markets. The volatility spillovers reveal that future trading could intensify volatility in the underlying spot market, perhaps due to the larger trading program and the speculative nature of the future trading. National Commodity and Derivatives Exchange Limited (NCDEX), being the largest agricultural commodity futures trading platform was purposively selected among all the National Commodity Exchanges, functioning in the country. The sampling design used for the study is purposive sampling which consists of five agricultural commodity derivatives viz., refined soya oil, guar seed, chana, soya bean and castor seed which were traded on the NCDEX platform. The study was purely based on secondary data which was drawn from the official website of NCDEX. The data comprised of daily closing spot prices and futures prices, with near month (expiration month) maturity, pertaining to the sample agricultural commodity derivatives traded on the exchange. The period of study was from January 2004 to November 2016. The volatility spillover between futures and spot prices of the sample agricultural commodity derivatives has been analyzed using bivariate EGARCH $(1,1)$ model. The results indicated that, even though there was a bidirectional volatility spillover, the spillover from futures market to spot market was stronger in case of all the sample agricultural commodity derivatives. The presence of leverage effect in both futures and spot market was evident, only in case of soya bean and castor seed. As far as the volatility persistence was concerned, it was quite high in case of most of the sample commodities, except castor seed.
\end{abstract}

KEYWORDS: Volatility Spillover, NCDEX, EGARCH, Leverage Effect \& Volatility Persistence

Received: Jul 08, 2017; Accepted: Jul 28, 2017; Published: Aug 03, 2017; Paper Id.: IJASRAUG201781

\section{INTRODUCTION}

Commodity derivatives are not new in India. In fact, forward trading in commodities existed in India from ancient times (it was mentioned in Kautilya's Arthashastra), but the first modern futures market was established in 1875 for cotton contracts by the Bombay Cotton Trade Association. After independence, the Forward Contracts (Regulation) Act was enacted in 1952 to regulate the trading in forward and futures. The Forward Markets Commission (FMC) which oversees forward trading was instituted as a regulatory body the following year. In 1966, futures trade was altogether banned to give effective powers to government price control. A few select commodities saw a reintroduction of futures in 1980, following the Khusro Committee report. But the real breakthrough came with the liberalization of the Indian economy in the early 1990's. In 1993, the Kabra Committee was appointed to look into 
forward markets. The committee recommended in 1994 that, all futures banned in 1966 to be reintroduced as well as many others added. Six years later, the National Agricultural Policy 2000 envisioned the removal of price controls in agricultural markets and widespread use of futures contracts. However, the commodity futures market made the true restart in early 2000's, with establishment of a number of nationwide multi commodity exchanges (Gupta, 2011).

In the Union Budget for FY 2015-16, the Honorable Union Finance Minister proposed the merger of Forward Markets Commission (FMC) with the Securities and Exchange Board of India (SEBI). FMC was merged with SEBI on September 28, 2015 and the Securities Contracts (Regulation) Act, 1956 was amended to include commodity derivatives within the definition of securities and Forward Contracts (Regulation) Act, 1952 (FCRA) was repealed. A total of 113 commodities have been permitted for trading in the commodities futures market, 38 commodities were actively traded at these exchanges, of which 28 were agricultural commodities and 10 were non-agricultural commodities. Among the agricultural commodities which were traded at the Indian commodities futures exchanges, NCDEX traded 18, MCX (5) and NMCE (6), during 2015-16 (SEBI, 2016).

\section{Volatility Spillover between Commodity Futures and Spot Markets}

Volatility spillover is described as the extent to which the volatility in one market affects the other and it is necessary to model the relationship between the volatilities of both markets. The volatility spillovers reveal that, future trading could intensify volatility in the underlying spot market, perhaps due to the larger trading program and the speculative nature of the future trading. The findings of the volatility spillover will reveal whether futures market reactions results in spillover, into the spot markets or vice versa. The existence of asymmetric volatility effect or leverage effect will help to analyze the comparative impact of positive shocks/good news and negative shocks/bad news, on volatility. The degree of volatility persistence will capture the impact of an information shock and the time taken by it to decay (Kumar and Shollapur, 2015).

Some of the researchers in India have studied the volatility spillover effects between the futures and spot markets pertaining to agricultural commodity derivatives. Mahalik et.al. (2009) concluded in his study that, in case of LAGRI (agriculture index); volatility spillover was stronger from spot to futures. Shihabudheen and Padhi (2010) concluded that, volatility spillover from futures market to spot market was stronger in case of majority of the selected agricultural commodities. Mukherjee (2011) concluded that, the volatility spillover from futures to spot market was stronger in case of wheat, chilli and soya oil. Malhotra and Sharma (2016) found out that, spillover effect from spot to futures was more than the spillover from futures to spot, in case of majority of the commodities except mustard seed. The existing literature on volatility spillover effects in the Indian commodity futures market has covered mainly non-agri commodities like precious metals, energy products etc., and the literature pertaining to agricultural commodity derivatives is very limited. The number of agricultural commodities covered in these studies are also very less and the time frame used for the analysis is also very short so as to come out with a meaningful inference. Hence there is lot of scope for doing volatility spillover study in the area of agricultural commodity derivatives.

Hence with reference to the aforesaid information, the main objective of the study is to analyze the volatility spillover between futures and spot market, in case of select agricultural commodity derivatives traded in India. 


\section{MATERIALS AND METHODS}

\section{Sampling}

The commodity exchange as well as the agricultural commodity derivatives used in the present study was selected using proportionate sampling technique. National Commodity and Derivatives Exchange Limited (NCDEX) being the largest agricultural commodity futures trading platform (Jha, 2015) was selected among all the National Commodity Exchanges functioning in the country. The same was confirmed from the annual reports of Forward Markets Commission (FMC) (2010-11 to 2013-14) and Securities and Exchange Board of India (SEBI) (2015-16). As of March 31st 2015, the Exchange offered trading in 26 commodities, which included 21 agricultural commodities, 2 bullion commodities, 2 metals and 1 commodity in energy \& polymer sector. This showed the dominance of agricultural commodity derivatives in the exchange in comparison with non-agri commodity derivatives.

Five agricultural commodity derivatives viz. refined soya oil, guar seed, chana, soya bean and castor seed were selected proportionate to the total value/volume traded at NCDEX. These commodity derivatives were selected based on their high value as well as trading volume and were consistently performing well on the NCDEX platform for many years. As per the annual reports of FMC (2009-10 to 2013-14) these were the top five commodities traded on the exchange and hence they formed a formidable base for the analysis.

\section{Data Collection}

The study was purely based on secondary data which was drawn from the official website of NCDEX. The data comprised of daily closing spot prices and futures prices with near month (expiration month) maturity pertaining to the sample agricultural commodity derivatives traded on the exchange. The near month futures contracts were selected for the analysis as they are considered as highly liquid and the most active contracts. The data on trading volume and open interest for the sample agricultural commodity derivatives was also collected on daily basis.

The period of study was from January 2004 to November 2016; however data period varied across the commodity derivatives owing to their late introduction on the commodity exchange and the fact that some commodity derivatives were banned for certain period in order to curb the speculative impacts which according to policy makers could have triggered inflation. Another reason for the variation is attributed to the availability of the futures and spot price data on the NCDEX website during the time of data collection. The list of sample commodities and their respective data period as well as reference market for spot price is given in the following Table 1.

Table 1: Data Period for the Sample Agricultural Commodity Derivatives

\begin{tabular}{|c|l|l|l|l|}
\hline Sl. No & \multicolumn{1}{|c|}{ Commodity } & \multicolumn{1}{|c|}{ Data Period } & Futures Market & Spot Market \\
\hline 1 & Refined soya oil & January 2004 - September 2016 & NCDEX & Indore \\
\hline 2 & Guar seed & June 2004 - November 2016 & NCDEX & Jodhpur \\
\hline 3 & Chana & June 2004 - July 2016 & NCDEX & Delhi \\
\hline 4 & Soya bean & January 2004 - October 2016 & NCDEX & Indore \\
\hline 5 & Castor seed & October 2004 - January 2016 & NCDEX & Deesa \\
\hline
\end{tabular}

Source: www.ncdex.com

\section{Tools of Analysis}

Time series data pertaining to the sample agricultural commodity derivatives was analyzed using various statistical and econometric tools. The base data of spot and futures prices was converted into continuous daily return series 
by taking natural logarithm. Natural logarithm of daily prices was taken to minimize the heteroscedasticity in data (Sehgal et.al., 2012). The rate of return for each day is defined as the difference between the natural $\log$ of a particular day's price and the natural log of the previous day's price.

$$
\mathrm{R}_{\mathrm{t}}=\left[\ln \left(P_{t}\right)-\ln \left(P_{t-1}\right)\right]
$$

Where, $R_{t}$ is the return for the day $t, \ln$ is the natural $\log , \mathrm{P}_{\mathrm{t}}$ and $\mathrm{P}_{\mathrm{t}-1}$ are the closing prices for day ' $\mathrm{t}$ ' and its previous trading day. However the base data of spot and futures prices was also used at appropriate stages of the analysis. The data was analyzed using MS Excel 2007 and Eviews-9 econometric software package.

The volatility spillover between futures and spot prices of the sample agricultural commodity derivatives is analyzed using the following econometric tools:

\section{Unit Root Test}

Augmented Dickey-Fuller test (ADF test) is employed to check the stationary of the series. If the series is nonstationary at levels and stationary at differences, then there exists a cointegration relationship between them which reveals the long-run relationship between the series (Kumar and Shollapur, 2015).

\section{Cointegration Test}

The nature of long-run equilibrium relationship between the spot and futures market for the sample agricultural commodity derivatives is ascertained using Johansen's Cointegration test. In practice many financial variables contain unit root and are thus said to be integrated at first difference [I (1)]. The cointegration test is based on maximum likelihood estimation and uses two test statistics, namely trace statistics $\left(\lambda_{\text {trace }}\right)$ and maximum Eigen value statistics $\left(\lambda_{\max }\right)$ to determine the number of cointegrating vectors (Johansen and Juselius, 1990).

\section{Bivariate EGARCH $(1,1)$ Model}

Tse (1999) uses a two-stage approach for estimating this model. First the residuals are generated using VECM model or through VAR model in case if the price series are not cointegrated. These residuals are used in the bivariate EGARCH model. The same approach is followed in the current study.

Vector Error Correction Model (VECM) is represented as:

$$
\begin{aligned}
& \Delta \mathrm{F}_{\mathrm{t}}=\alpha_{f}+\lambda_{f} e_{t-1}+\sum_{i=1}^{r} \gamma_{f, i} \Delta f_{t-i}+\sum_{i=1}^{r} \omega_{s, i} \Delta s_{t-i}+\varepsilon_{f t} \\
& \Delta \mathrm{S}_{\mathrm{t}}=\alpha_{s}+\lambda_{s} e_{t-1}+\sum_{i=1}^{r} \gamma_{s, i} \Delta s_{t-i}+\sum_{i=1}^{r} \omega_{f, i} \Delta f_{t-i}+\varepsilon_{s t}
\end{aligned}
$$

The VAR model is represented as:

$$
\begin{aligned}
& \Delta \mathrm{F}_{\mathrm{t}}=\alpha_{f}+\sum_{i=1}^{r} \gamma_{f, i} \Delta f_{t-i}+\sum_{i=1}^{r} \omega_{s, i} \Delta s_{t-i}+\varepsilon_{f t} \\
& \Delta \mathrm{S}_{\mathrm{t}}=\alpha_{s}+\sum_{i=1}^{r} \gamma_{s, i} \Delta s_{t-i}+\sum_{i=1}^{r} \omega_{f, i} \Delta f_{t-i}+\varepsilon_{s t}
\end{aligned}
$$

Where, $\Delta \mathrm{F}_{\mathrm{t}}$ : Vector of $\log$ futures price (futures returns), $\Delta \mathrm{S}_{\mathrm{t}}:$ Vector of log spot price (spot returns), $\alpha_{f}$ and $\alpha_{s}$ : Intercepts, $\lambda_{f}$ and $\lambda_{s}$ : Coefficients of long-term error correction terms/speed of adjustment parameters, $e_{t-1}$ : Error correction term, $\gamma_{f, i}$ and $\gamma_{s, i}$ : Short term coefficients, $\omega_{s, i}$ and $\omega_{f, i}$ : Short term coefficients, $\varepsilon_{f t}$ and $\varepsilon_{s t}$ : White noise disturbance terms 
The residuals generated from the aforementioned VECM/VAR models are used in the bivariate EGARCH $(1,1)$ model:

$$
\begin{aligned}
& \ln \left(\sigma_{\mathrm{f}, t}^{2}\right)=\alpha_{f}+\beta_{f}\left[\left|\frac{\varepsilon_{s, t-1}}{\sigma_{s, t-1}}\right|-E\left|\frac{\varepsilon_{s, t-1}}{\sigma_{s, t-1}}\right|\right]+\theta_{f}\left[\frac{\varepsilon_{f, t-1}}{\sigma_{f, t-1}}\right]+\varphi_{f} \ln \left(\sigma_{f, t-1}^{2}\right) \\
& \ln \left(\sigma_{\mathrm{s}, t}^{2}\right)=\alpha_{s}+\beta_{s}\left[\left|\frac{\varepsilon_{f, t-1}}{\sigma_{f, t-1}}\right|-E\left|\frac{\varepsilon_{f, t-1}}{\sigma_{f, t-1}}\right|\right]+\theta_{s}\left[\frac{\varepsilon_{s, t-1}}{\sigma_{s, t-1}}\right]+\varphi_{s} \ln \left(\sigma_{s, t-1}^{2}\right)
\end{aligned}
$$

In the above equations (5) and $(6), \ln \left(\sigma_{\mathrm{f}, \mathrm{t}}^{2}\right)$ and $\ln \left(\sigma_{\mathrm{s}, \mathrm{t}}^{2}\right)$ represent conditional time-varying variances of futures and spot returns. It is conditional on the assumption that $\varepsilon_{f t}$ and $\varepsilon_{s t}$ are normally distributed with zero mean and variances of $\sigma_{\mathrm{f}, \mathrm{t}}^{2}$ and $\sigma_{\mathrm{s}, t}^{2} \cdot \varepsilon_{f t}$ and $\varepsilon_{s t}$ are the residuals generated from equations (1),(2),(3) and (4) of VECM/VAR models. $\beta_{f}$ captures the volatility spillover from futures market to spot market. $\theta_{f}$ And $\theta_{s}$ capture the asymmetric behavior or the leverage effect, which indicates whether bad news has a greater impact on the volatility as against good news. $\varphi_{f}$ and $\varphi_{s}$ represent the degree of volatility persistence or the time taken for the impact of new information to taper off.

\section{RESULTS}

\section{Unit Root Test}

The presence of unit root was tested for the futures and spot price series of the select agricultural commodity derivatives viz. refined soya oil, guar seed, chana, soya bean and castor seed using ADF test and the results are presented in the Table 2. The price series were tested at the base level as well as at the first difference. In case of refined soya oil, chana, soya bean and castor seed, both the price series were exhibiting the presence of unit root when tested using their level data. Therefore the price series at level was found to be non-stationary in both the futures and spot markets in case of these commodity derivatives.

The same estimation procedure was conducted for both the price series at their first difference and it could be observed that there was no unit root in the data. Therefore the price series at first difference was found to be stationary in both the futures and spot markets for refined soya oil, chana, soya bean and castor seed. Since the two price series were [I (1)] or integrated at first difference, it was possible to test for the cointegrating relationship using Johansen's Cointegration test. However the case was not the same in case of futures and spot price series of guar seed as they were found to be stationary when tested using their level data itself. As a result it didn't qualify for Johansen's Cointegration test which also confirmed that there wasn't any long run equilibrium relationship present between the two price series of guar seed.

Table 2: Stationarity Test Results

\begin{tabular}{|l|l|c|c|c|c|c|}
\hline \multirow{2}{*}{ Commodity } & \multirow{2}{*}{ Price Series } & \multicolumn{2}{|c|}{ ADF Test Statistics } & \multicolumn{2}{c|}{$p$-value\# } & \multirow{2}{*}{ Order of Integration } \\
\cline { 3 - 6 } & & L. & F.D. & L. & F.D. & \\
\hline \multirow{2}{*}{ Refined Soya Oil } & Futures & -2.71 & $-55.65^{*}$ & 0.23 & $0.00^{*}$ & $\mathrm{I}(1)$ \\
\cline { 2 - 6 } & Spot & -2.51 & $-45.28^{*}$ & 0.32 & $0.00^{*}$ & $\mathrm{I}(1)$ \\
\hline \multirow{2}{*}{ Chana } & Futures & 0.48 & $-52.96^{*}$ & 0.99 & $0.00^{*}$ & $\mathrm{I}(1)$ \\
\cline { 2 - 6 } & Spot & 0.90 & $-52.76^{*}$ & 0.99 & $0.00^{*}$ & $\mathrm{I}(1)$ \\
\hline \multirow{2}{*}{ Soya bean } & Futures & -3.07 & $-56.69^{*}$ & 0.11 & $0.00^{*}$ & $\mathrm{I}(1)$ \\
\cline { 2 - 6 } & Spot & -2.70 & $-46.12^{*}$ & 0.24 & $0.00^{*}$ & $\mathrm{I}(1)$ \\
\hline \multirow{2}{*}{ Castor seed } & Futures & -1.70 & $-48.40^{*}$ & 0.75 & $0.00^{*}$ & $\mathrm{I}(1)$ \\
\cline { 2 - 6 } & Spot & -1.52 & $-37.86^{*}$ & 0.82 & $0.00^{*}$ & $\mathrm{I}(1)$ \\
\hline \multirow{2}{*}{ Guar seed } & Futures & $-4.34^{*}$ & $-19.79^{*}$ & $0.00^{*}$ & $0.00^{*}$ & $\mathrm{I}(0)$ \\
\cline { 2 - 5 } & Spot & $-4.89^{*}$ & $-20.14^{*}$ & $0.00^{*}$ & $0.00^{*}$ & $\mathrm{I}(0)$ \\
\hline
\end{tabular}

Note: L: Level; F.D: First Difference; \#: MacKinnon (1996) one-sided p-values. Null Hypothesis $\left(\mathrm{H}_{0}\right)$ of ADF 
test is that the series has unit root. * denotes significance at 5 per cent level and hence rejection of the null hypothesis. Critical value at 5 per cent was -3.41 in all the cases. Absolute values are considered while comparing test statistics and critical values.

\section{Cointegration Test}

The presence of cointegrating relationship between the futures and spot price series of refined soya oil, chana, soya bean and castor seed was tested using Johansen's Cointegration test and the results are presented in the Table 3 . The test was conducted for the existence of number of hypothesized cointegrating equations. The number of lags selected for the test was four, which was based on the lag selection criterion. The hypothesis that there is no cointegrating relationship between futures and spot price series was rejected as the probability value was found to be lesser than 5 per cent. The statistics for Trace test as well as Maximum Eigen value test were exceeding their respective critical values. Further it indicated the presence of at least one cointegrating equation between the futures and spot price series. The hypothesis that there is at most one cointegrating equation between the futures and spot price series was accepted as the probability value was more than 5 per cent. The statistics for Trace test as well as Maximum Eigen value test were found to be lesser than their respective critical values. Therefore it could be inferred that the futures and spot price series for refined soya oil, chana, soya bean and castor seed were cointegrated and exhibiting a long run equilibrium relationship. The presence of cointegrating relationship also confirmed that there was a causal relationship between the futures and spot price series, at least in one direction.

Table 3: Johansen's Cointegration Test Results

\begin{tabular}{|c|c|c|c|c|c|c|c|}
\hline \multirow[b]{2}{*}{ Commodity } & \multirow{2}{*}{$\begin{array}{c}\text { Hypothesized } \\
\text { No. of } \\
\text { Cointegrating } \\
\text { Equations }\end{array}$} & \multicolumn{2}{|c|}{ Trace Test } & \multicolumn{2}{|c|}{ Max. Eigen Value } & \multirow[b]{2}{*}{$p$-Value\# } & \multirow[b]{2}{*}{ Lags } \\
\hline & & Statistics & $\begin{array}{l}\text { Critical } \\
\text { Values }\end{array}$ & Statistics & $\begin{array}{l}\text { Critical } \\
\text { Values }\end{array}$ & & \\
\hline \multirow{2}{*}{$\begin{array}{l}\text { Refined } \\
\text { Soya Oil }\end{array}$} & None & 155.80 & 15.49 & 153.52 & 14.26 & $0.00^{*}$ & \multirow{2}{*}{4} \\
\hline & At most 1 & 2.28 & 3.84 & 2.28 & 3.84 & 0.13 & \\
\hline \multirow{2}{*}{ Chana } & None & 115.74 & 25.87 & 109.73 & 19.39 & $0.00^{*}$ & \multirow{2}{*}{4} \\
\hline & At most 1 & 6.01 & 12.52 & 6.01 & 12.52 & 0.46 & \\
\hline \multirow{2}{*}{ Soya bean } & None & 112.49 & 15.49 & 110.21 & 14.26 & $0.00^{*}$ & \multirow{2}{*}{2} \\
\hline & At most 1 & 2.28 & 3.84 & 2.28 & 3.84 & 0.13 & \\
\hline \multirow{2}{*}{ Castor seed } & None & 103.56 & 15.49 & 102.14 & 14.26 & $0.00^{*}$ & \multirow{2}{*}{4} \\
\hline & At most 1 & 1.42 & 3.84 & 1.42 & 3.84 & 0.23 & \\
\hline
\end{tabular}

Note: *denotes rejection of null hypothesis $\left(\mathrm{H}_{0}\right)$ at 5 per cent level of significance. \# MacKinnon-Haug-Michelis (1999) p-values

\section{Bivariate EGARCH $(1,1)$ Model}

After ascertaining the presence of cointegration, VECM model was applied and the residuals were generated in case of refined soya oil, chana and soya bean and castor seed. In case of guar seed, VAR model was applied to generate the residuals. Before estimating the $\operatorname{EGARCH}(1,1)$ model, the presence of serial correlation among residuals of VECM/VAR models, for the sample agricultural commodity derivatives was tested using Ljung-Box Q-statistics at 36 lags, presented in the Table 4. The squared normalized residuals were found to be significant in case of most of the sample agricultural commodity derivatives, except guar seed. This confirmed the presence of ARCH effect and also indicated the existence of heteroscedasticity in the VECM. Therefore, it confirmed the necessity for using the EGARCH $(1,1)$ model to analyze the volatility spillover between futures and spot market. 
Table 4: Autocorrelation Function of the Standardized Squared Residuals from VECM/VAR for the Sample Agricultural Commodity Derivatives

\begin{tabular}{|c|c|c|c|c|c|c|c|c|c|}
\hline \multirow{2}{*}{ Commodity } & \multirow{2}{*}{ Lags } & \multicolumn{4}{|c|}{ Panel 1: Futures Return Equation } & \multicolumn{4}{|c|}{ Panel 2: Spot Return Equation } \\
\hline & & $\mathbf{A C}$ & PAC & Q-Stat. & Prob. & $\mathbf{A C}$ & PAC & Q-Stat. & Prob. \\
\hline Refined soya oil & \multirow{5}{*}{36} & 0.02 & 0.01 & 183.20 & $0.00^{*}$ & 0.02 & 0.01 & 232.84 & $0.00^{*}$ \\
\hline Guar seed & & 0.00 & 0.00 & 9.95 & 0.75 & 0.00 & 0.00 & 6.62 & 0.85 \\
\hline Chana & & 0.03 & 0.02 & 120.51 & $0.00^{*}$ & 0.04 & 0.02 & 260.11 & $0.00^{*}$ \\
\hline Soya bean & & 0.01 & 0.01 & 84.52 & $0.00^{*}$ & 0.04 & 0.02 & 727.14 & $0.00^{*}$ \\
\hline Castor seed & & 0.01 & 0.01 & 144.39 & $0.00^{*}$ & 0.01 & 0.01 & 148.96 & $0.00^{*}$ \\
\hline
\end{tabular}

Note: Ljung and Box (1978) $Q$-statistics for the standardized squared residuals obtained from VECM/VAR. LjungBox test statistic tests the null hypothesis of absence of autocorrelation.

\section{Volatility Spillover Effect}

The volatility spillover between futures and spot market for refined soya oil, guar seed, chana, soya bean and castor seed was analyzed using bivariate EGARCH $(1,1)$ model and the results are presented in the Table 5. In the panel 1 variance of futures return was taken as dependent variable and spot return variance as explanatory variable. Similarly in the panel 2 variance of spot return was taken as dependent variable and futures return variance as explanatory variable. The coefficients $\beta_{f}$ and $\beta_{s}$ were used to measure the volatility spillover between the futures and spot markets. It could be observed from the table that there was a bidirectional volatility spillover in case of all the commodity derivatives as both $\beta_{f}$ and $\beta_{s}$ were found to be statistically significant. However, based on the magnitude of the coefficients it could be concluded that volatility spillover was stronger from futures market to spot market. In general, both the markets were reacting to the new information but it was the futures market reactions which resulted in spillover into the spot markets.

\section{Leverage Effect}

The existence of asymmetric volatility effect or leverage effect was indicated by the $\theta_{f}$ and $\theta_{s}$ coefficients. These leverage coefficients were supposed to be negative and statistically significant in order to confirm the leverage effect. It could be seen from the table that this condition was not satisfied in either of the variance equations in case of refined soya oil, guar seed and chana. Therefore, it could be concluded that, there was no leverage effect for refined soya oil in futures market and spot market. In other words, it was not possible to conclude that bad news (market retreats) had greater impact than good news (market advances). On the contrary, the presence of leverage effect in both futures and spot market was evident in case of soya bean and castor seed. Hence, it could be concluded that in these two commodities bad news (market retreats) on volatility was having a greater impact than good news (market advances) on volatility.

Table 5: Estimates of Bivariate EGARCH $(1,1)$ Model

\begin{tabular}{|c|c|c|c|c|c|c|c|c|}
\hline \multirow[t]{2}{*}{ Commodity } & \multirow[t]{2}{*}{ Coefficient } & \multicolumn{3}{|c|}{$\begin{array}{c}\text { Panel 1: Futures Return } \\
\text { Variance (Dependent variable) }\end{array}$} & \multirow[t]{2}{*}{ Coefficient } & \multicolumn{3}{|c|}{$\begin{array}{l}\text { Panel 2: Spot Return Variance } \\
\text { (Dependent Variable) }\end{array}$} \\
\hline & & Value & S.E. & z-Statistic & & Value & S.E. & z-Statistic \\
\hline \multirow{6}{*}{$\begin{array}{l}\text { Refined } \\
\text { Soya Oil }\end{array}$} & $\alpha_{f}$ & -0.112 & 0.006 & $-18.536^{*}$ & $\alpha_{s}$ & -0.034 & 0.004 & $-8.106^{*}$ \\
\hline & $\beta_{f}$ & 0.112 & 0.005 & $21.327^{*}$ & $\beta_{s}$ & 0.152 & 0.005 & $29.845^{*}$ \\
\hline & $\theta_{f}$ & -0.025 & 0.009 & -2.780 & $\theta_{s}$ & 0.047 & 0.007 & $6.433^{*}$ \\
\hline & $\varphi_{f}$ & 0.996 & 0.001 & $1920.572^{*}$ & $\varphi_{s}$ & 1.007 & 0.001 & $1513.719^{*}$ \\
\hline & \multirow{2}{*}{\multicolumn{2}{|c|}{ Residual Diagnostics }} & LB & 2.877 & \multirow{2}{*}{\multicolumn{2}{|c|}{ Residual Diagnostics }} & LB & $6.512^{*}$ \\
\hline & & & ARCH & 0.492 & & & ARCH & 8.346 \\
\hline \multirow{3}{*}{ Guar seed } & $\alpha_{f}$ & -0.036 & 0.003 & $-12.105^{*}$ & $\alpha_{s}$ & -0.319 & 0.025 & $-12.760^{*}$ \\
\hline & $\beta_{f}$ & 0.069 & 0.005 & $14.797^{*}$ & $\beta_{s}$ & 0.262 & 0.010 & $26.500^{*}$ \\
\hline & $\theta_{f}$ & 0.075 & 0.004 & $20.621^{*}$ & $\theta_{s}$ & 0.070 & 0.009 & $8.044^{*}$ \\
\hline
\end{tabular}




\begin{tabular}{|c|c|c|c|c|c|c|c|c|}
\hline & $\varphi_{f}$ & 1.002 & 0.000 & $2353.707^{*}$ & $\varphi_{s}$ & 0.985 & 0.002 & $441.178^{*}$ \\
\hline & \multirow{2}{*}{\multicolumn{2}{|c|}{ Residual Diagnostics }} & LB & 9.304 & \multirow{2}{*}{\multicolumn{2}{|c|}{ Residual Diagnostics }} & LB & 25.304 \\
\hline & & & ARCH & 0.484 & & & ARCH & 0.249 \\
\hline \multirow{6}{*}{ Chana } & $\alpha_{f}$ & -15.317 & 0.110 & $-139.387^{*}$ & $\alpha_{s}$ & -0.184 & 0.016 & $-11.790^{*}$ \\
\hline & $\beta_{f}$ & 0.073 & 0.008 & $8.885^{*}$ & $\beta_{s}$ & 0.159 & 0.005 & $29.366^{*}$ \\
\hline & $\theta_{f}$ & -0.002 & 0.004 & -0.529 & $\theta_{s}$ & 0.046 & 0.005 & $8.764^{*}$ \\
\hline & $\varphi_{f}$ & -0.912 & 0.013 & $-70.145^{*}$ & $\varphi_{s}$ & 0.992 & 0.002 & $615.878^{*}$ \\
\hline & \multirow{2}{*}{\multicolumn{2}{|c|}{ Residual Diagnostics }} & LB & $77.999^{*}$ & \multirow{2}{*}{\multicolumn{2}{|c|}{ Residual Diagnostics }} & LB & $30.151^{*}$ \\
\hline & & & ARCH & $12.899^{*}$ & & & ARCH & $12.191^{*}$ \\
\hline \multirow{6}{*}{ Soya bean } & $\alpha_{f}$ & -15.906 & 0.030 & $-531.947^{*}$ & $\alpha_{s}$ & -1.121 & 0.070 & $-16.064^{*}$ \\
\hline & $\beta_{f}$ & 0.010 & 0.003 & $3.772^{*}$ & $\beta_{s}$ & 0.416 & 0.014 & $30.529^{*}$ \\
\hline & $\theta_{f}$ & -0.058 & 0.002 & $-24.050^{*}$ & $\theta_{s}$ & -0.081 & 0.013 & $-6.073^{*}$ \\
\hline & $\varphi_{f}$ & -0.954 & 0.003 & $-335.826^{*}$ & $\varphi_{s}$ & 0.911 & 0.007 & $128.565^{*}$ \\
\hline & \multirow{2}{*}{\multicolumn{2}{|c|}{ Residual Diagnostics }} & LB & $222.276^{*}$ & \multirow{2}{*}{\multicolumn{2}{|c|}{ Residual Diagnostics }} & LB & 9.196 \\
\hline & & & ARCH & $70.088^{*}$ & & & ARCH & 0.021 \\
\hline \multirow{6}{*}{ Castor seed } & $\alpha_{f}$ & -4.828 & 0.154 & $-31.358^{*}$ & $\alpha_{s}$ & -5.166 & 0.137 & $-37.675^{*}$ \\
\hline & $\beta_{f}$ & 1.209 & 0.023 & $51.997^{*}$ & $\beta_{s}$ & 1.216 & 0.022 & $55.148^{*}$ \\
\hline & $\theta_{f}$ & -0.857 & 0.022 & $-38.937^{*}$ & $\theta_{s}$ & -0.952 & 0.021 & $-44.395^{*}$ \\
\hline & $\varphi_{f}$ & 0.468 & 0.019 & $24.343^{*}$ & $\varphi_{s}$ & 0.444 & 0.016 & $27.926^{*}$ \\
\hline & \multirow{2}{*}{\multicolumn{2}{|c|}{ Residual Diagnostics }} & LB & 1.398 & \multirow{2}{*}{\multicolumn{2}{|c|}{ Residual Diagnostics }} & LB & 4.865 \\
\hline & & & ARCH & 0.827 & & & ARCH & 3.810 \\
\hline
\end{tabular}

Note: * denotes significance at 5 per cent level; SE: Standard Error; LB: Ljung-Box Test for autocorrelation with 36 lags; and ARCH-LM Test.

\section{Volatility Persistence}

The degree of volatility persistence was captured by $\varphi_{f}$ and $\varphi_{s}$ coefficients. Here the absolute values of the coefficients were considered which indicated the presence of volatility persistence. If the values were larger, then it meant that the impact of an information shock was taking longer time to decay. In other words, information arriving on a particular day was impacting that day's volatility as well as the following day's volatilities. It could be seen from the table that the volatility persistence was very high (i.e. >0.90) and statistically significant in case of both futures and spot markets for refined soya oil, guar seed, chana and soya bean. Hence the impact created by the new information was affecting the volatility in futures as well as spot markets for a longer time period. But in case of castor seed volatility persistence was lower (i.e. $<0.90$ ) and hence the impact created by the new information was affecting the volatility in futures as well as spot markets for a shorter time period.

Finally, the diagnostic checking was done for the squared residuals of the futures return variance equation and spot return variance equation. Ljung-Box (LB) test and ARCH-LM test were employed for testing autocorrelation and ARCH effect respectively. In case of refined soya oil, guar seed and castor seed there was clearly no ARCH effect in both the variance equations as the coefficients were found to be statistically insignificant. Therefore the bivariate EGARCH model was reasonably well specified and the most appropriate model to capture the $\mathrm{ARCH}$ effects (time-varying volatility) in the time series analyzed. In case of chana it was confirmed that still there was serial correlation as well as ARCH effect in both the variance equations as the coefficients were found to be statistically significant and in case of soya bean there was serial correlation as well as ARCH effect in futures return variance equation. Therefore the bivariate EGARCH model was not able to fully eliminate the ARCH effect in these two commodities.

The volatility spillover and its associated effects such as leverage effect and volatility persistence were analyzed for the sample agricultural commodity derivatives using bivariate EGARCH $(1,1)$ model. Even though there was a 
bidirectional volatility spillover, the spillover from futures market to spot market was stronger in case of all the sample agricultural commodity derivatives. These results were similar to the findings of the study conducted by Kumar and Shollapur (2015). On the contrary, the findings of the study conducted by Srinivasan (2012) showed the occurrence of spillover from spot market to futures market and the main reason identified for this variation was the selection of MCXAGRI indices for the study. The presence of leverage effect in both futures and spot market was evident only in case of soya bean and castor seed. As far as the volatility persistence was concerned, it was quite high in case of most of the sample commodities except castor seed.

\section{CONCLUSIONS}

In the present study, the volatility spillover between the futures and spot markets in case of select agricultural commodity derivatives traded at NCDEX has been analyzed. The commodity derivatives viz., refined soya oil, guar seed, chana, soya bean and castor seed form the major chunk of the agricultural commodities traded at NCDEX both in terms of value as well as volume. Even though bidirectional volatility spillover was observed in case of the select agricultural commodity derivatives, there was a stronger spillover from futures to spot. As a result, spot market for these commodities will be affected whenever there is a high volatility in futures market. Hence the investors operating in the spot market of these commodities should be always aware of the degree of volatility prevalent in the futures market. It is also the responsibility of the futures market regulator SEBI to take appropriate measures and to frame suitable policies towards curbing the high volatilities in futures market which may affect the stability of the spot market.

\section{REFERENCES}

1. Ajoy Kumar, M. and Shollapur, M.R. (2015). Price Discovery and Volatility Spillover in the Agricultural Commodity Futures Market in India. The IUP Journal of Applied Finance, 21(1), 54-70.

2. Kedarnath Mukherjee (2011). Impact of Futures Trading on Indian Agricultural Commodity Market. Munich Personal RePEc Archive, (29290), 1-47.

3. Meenakshi Malhotra and Dinesh Kumar Sharma (2016). Volatility Dynamics in Oil and Oilseeds Spot and Futures Market in India. The Journal for Decision Makers, 41(2), 132-148.

4. Rajnarayan Gupta (2011). Commodity Derivative Market in India: The Past, Present and Future. Analytique, 7(2), 4-9.

5. Sanjay Sehgal, Namita Rajput and Rajeev Kumar Dua (2012). Price Discovery in Indian Agricultural Commodity Markets. International Journal of Accounting and Financial Reporting, 2(2), 34-54.

6. Soren Johansen and Katarina Juselius (1990). Maximum Likelihood Estimation and Inference on Cointegration-With Applications to the Demand for Money. Oxford Bulletin of Economics and Statistics, 52.2(1990), 169-210.

7. Srinivasan, P. (2012). Price Discovery and Volatility Spillovers in Indian Spot-Futures Commodity Market. The IUP Journal of Behavioral Finance, 9(1), 71-85.

8. Yiuman Tse (1999). Price discovery and volatility spillovers in the DJIA index and futures markets. The Journal of Futures Markets, 19(8), 911-930.

9. Forward Markets Commission. (2010). 2009-10 Annual Report of the Forward Markets Commission. Mumbai: Author.

10. Forward Markets Commission. (2011). 2010-11 Annual Report of the Forward Markets Commission. Mumbai: Author.

11. Forward Markets Commission. (2012). 2011-12 Annual Report of the Forward Markets Commission. Mumbai: Author. 
12. Forward Markets Commission. (2013). 2012-13 Annual Report of the Forward Markets Commission. Mumbai: Author.

13. Forward Markets Commission. (2014). 2013-14 Annual Report of the Forward Markets Commission. Mumbai: Author.

14. Mantu Kumar Mahalik, Debashis Acharya and Suresh Babu, M. (2009). Price Discovery and Volatility Spillovers in Futures and Spot Commodity Markets: Some Empirical Evidence from India. Mumbai: Indira Gandhi Institute of Development Research.

15. Securities and Exchange Board of India. (2016). 2015-16 Annual Report of the Securities and Exchange Board of India. Mumbai: Author.

16. Dilip Kumar Jha. (2015, April 7). NCDEX may provide technical assistance to Myanmar Commodity Exchange. Business Standard. Retrieved from

http://www.businessstandard.com/article/companies/ncdexmayprovidetechnicalassistancetomyanmarcommodityexchange1150 40700913_1.html

17. https://www.ncdex.com/index.aspx 